\title{
Anti-oxidant Activities of Phytol on Keratinocytes
}

Sun-Hee Jeong

Department of Beauty Arts, Suwon Women's University, Suwon-si, Gyeonggi-do, Korea

Corresponding author: Sun-Hee Jeong, Department of Beauty Arts, Suwon Women's University, 72 Onjeong-ro, Gwonseon-gu, Suwon-si, Gyeonggi-do 16632, Korea

Tel.: +82 312908375

Fax: +82 312908047

Email: sunheejeong@swc.ac.kr

Received June 11, 2017

Revised September 21, 2017

Accepted September 28, 2017

Published December 30, 2017

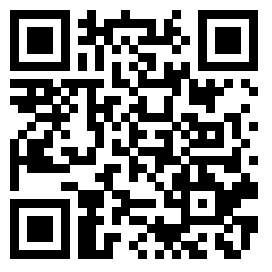

\begin{abstract}
Purpose: The aim purpose of this study is to evaluate anti-oxidant and cytoprotective effects of phytol as an ingredient of cosmetic against hydrogen peroxide $\left(\mathrm{H}_{2} \mathrm{O}_{2}\right)$ in keratinocytes. Methods: Cell viability assay, 2,2-diphenyl-1-picrylhydrazyl (DPPH) assay, 2',7'-dichlorofluorescin diacetate (DCFDA) assay, reactive oxygen species (ROS) scavenging activity assay, flow cytometry analysis, quantitative real-time polymerase chain reaction (qRT-PCR), and glutathione assay were performed to verify the cell effectiveness of phytol. Results: To determine the experimental concentration of $\mathrm{H}_{2} \mathrm{O}_{2}$ and phytol in $\mathrm{HaCaT}$ keratinocytes, water-soluble tetrazolium salt (WST-1) assay was examined with treatments of various $\mathrm{H}_{2} \mathrm{O}_{2}$ and phytol concentrations in HaCaT keratinocytes. As a results $750 \mu \mathrm{M} \mathrm{H}_{2} \mathrm{O}_{2}$ and $10 \mu \mathrm{M}$ phytol treatment was chosen for the experiment. The expression of copper-zinc superoxide dismutase (CuZn-SOD; SOD1), manganese superoxide dismutase (Mn-SOD; $S O D 2)$, catalase (CAT) mRNA, very well-known as anti-oxidant genes, was increased by phytol in a dose-dependent manner. DPPH radical scavenging activity and intracellular reduced form of glutathione (GSH) levels were increased by phytol in a dose-dependent manner, which showed that anti-oxidant effects are recovered by phytol. Conclusion: It suggests possibility of phytol as a cosmetic ingredient which enhances a defense system and slows an ageing process for skin.
\end{abstract}

Keywords: Phytol, Anti-oxidant, Cytoprotective, Cosmetics, Ageing

\section{Introduction}

신체에서 피부는 다양한 환경적인 요인에 대해 개체를 보 호하는 일차적인 물리적 장벽으로서의 중요한 역할을 담당 하고 있다. 이러한 피부는 크게 표피, 진피, 피하지방조직으 로 구성되며, 최외각 층에 있는 표피는 대부분 각질형성세 포(keratinocytes)로 구성되어 있다. Keratinocytes는 표피 의 기저층에서 각질층까지 단계를 거치면서 분화되고, 이러 한 과정을 통해 피부장벽기능을 수행한다. 하지만 생체의 최 외각 층에 존재하고 있어, ultraviolet (UV), 열, 환경독소 등 과 같은 외적 요인에 의해 영향을 받기 쉽다. 이와 같은 산화 적 스트레스(oxidative stress)는 피부에 축적되어 궁극적으 로 피부노화로 이어지게 된다. 피부노화의 주된 원인 중 하 나인 활성산소종(ROS)은 대표적인 예로 superoxide anion $\left(\mathrm{O}_{2}^{-}\right)$, nitric oxide $(\mathrm{NO})$, hydroxyl radical $\left(\mathrm{OH}^{-}\right)$, singlet oxygen $\left({ }^{1} \mathrm{O}_{2}\right), \mathrm{H}_{2} \mathrm{O}_{2}$ 등이 있다(Thannickal \& Fanburg, 2000; Park \& Shim, 2016). 이러한 ROS는 미토콘드리아의
전자 전달계에서 산소가 수소이온과 전자를 받아 물로 치환되 어 adenosine triphosphate (ATP)를 형성하게 되는데 이때 대략 1-2\%의 홀 전자가 산소에 전해져 생성된다(Halliwell \& Gutteridge, 1989). 이와 같이 ROS는 세포 내 정상적인 활 성 작용 과정에 의하여 생성되며, 세포신호와 증식, DNA 복 제, 사이토카인에 대한 반응 정도를 포함한 다양한 생물학적 과정에 연관되어 있다(Gao et al., 2001; Rhee, 2006). 따라 서 $\mathrm{ROS}$ 의 항상성을 유지하는 것은 세포 성장과 생존에 매우 중요하다.

하지만 약물, 자외선, 공해물질, 감염 등과 같이 외부 인 자들에 의해서 $\mathrm{ROS}$ 생성이 촉진되기도 한다. $\mathrm{ROS}$ 노출량 과 지속시간이 증가되고 $\mathrm{ROS}$ 방어기작이 돌연변이를 일으 키게 되면 항산화제 양이 감소하여 산화-환원 항상성이 무 너져 산화적 스트레스가 유발된다. 여기서 산화적 스트레스 란 ROS 발생과 체내 항산화 효소의 활동과 같은 항산화 반응 이 균형을 이루지 못해 활성산소가 축적되는 상태를 말한다. 이러한 산화적 스트레스는 세포 내 지질과산화, 단백질 변성, 


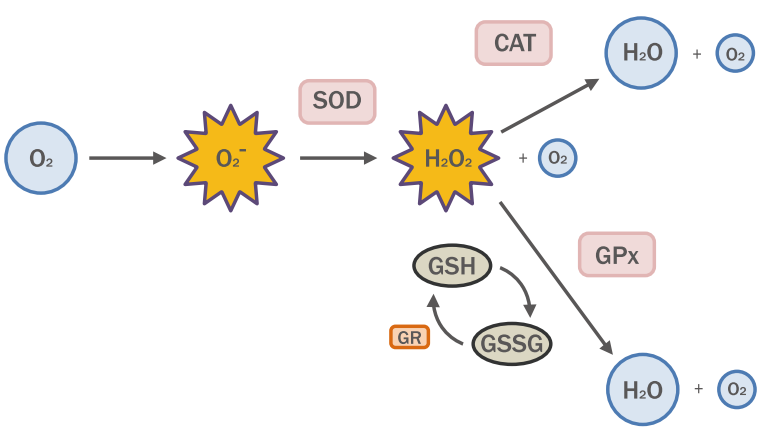

Figure 1. Anti-oxidant pathways of ROS.

ROS comprise both free radical and non-free radical oxygen containing molecules such as $\mathrm{H}_{2} \mathrm{O}_{2}$ and $\mathrm{O}_{2}$. Cellular redox homeostasis is maintained by an endogenous anti-oxidant defense system, which includes endogenous anti-oxidant enzymes such as SOD, CAT, GPx, and GSH. ROS, reactive oxygen species; $\mathrm{H}_{2} \mathrm{O}_{2}$, hydrogen peroxide; $\mathrm{O}_{2}^{-}$, superoxide; SOD, superoxide dismutase; CAT, catalase; GPx, glutathione peroxidase; GSH, reduced form of glutathione; GSSG, oxidized form of glutathione; $\mathrm{GR}$, glutathione reductase.

$\mathrm{DNA}$ 손상, 세포괴사 등을 일으켜 결국 노화를 일으키게 된다 (Ozben, 2007; Rhee, 2006).

산화적 스트레스로부터 생체를 보호하기 위해 세포에는 내재적 방어기전인 superoxide dismutase (SOD), CAT, glutathione peroxidase (GPx) 등의 항산화 효소와 ascorbic acid, glutathione 등의 비효소적 항산화제가 있다(Slater, 1984). 항산화 효소와 비효소적 항산화제는 상호 의존적으 로 활동하며 세포 내 다양한 항산화제 시스템(endogenous antioxidant system)을 작동시키고 있다. 건강한 상태의 세 포 내에서는 이러한 다양한 메커니즘을 통해 해로운 산화 경 로를 억제함으로써 세포 상해로부터 스스로를 보호하고, 항상 성을 유지한다.

인체 내 대표적인 1차적 초기 항산화 효소인 $\mathrm{SOD}$ 는 활성산 소를 $\mathrm{H}_{2} \mathrm{O}_{2}$ 와 $\mathrm{O}_{2}$ 로 전환시키고, 생성된 $\mathrm{H}_{2} \mathrm{O}_{2}$ 는 CAT와 $\mathrm{GPx}$ 에 의해 소거된다. GPx는 reduced form of glutathione (GSH)을 oxidized form of glutathione (GSSG)로 산화시 키면서 $\mathrm{H}_{2} \mathrm{O}_{2}$ 를 제거한다(Figure 1). 여기서 $\mathrm{GSH}$ 는 생체내의 주요 항산화 성분으로 자신의 thiol을 이용하여 활성산소를 제거하며 세포 내 해독작용을 한다(Dickinson \& Forman, 2002; Lee et al., 2017).

산화적 스트레스로부터 세포를 보호하는데 강한 항암 작용 및 면역증강 효과가 있다고 알려진 phytol은 식물조직에서 녹 색의 색소성분인 클로로필의 구성성분으로 존재하며 식물 조 직 파괴 시 가수분해되어 생성된다(Gross, 1991). Phytol이 강한 면역 효과가 있다는 선행연구결과를 바탕으로 인간각질

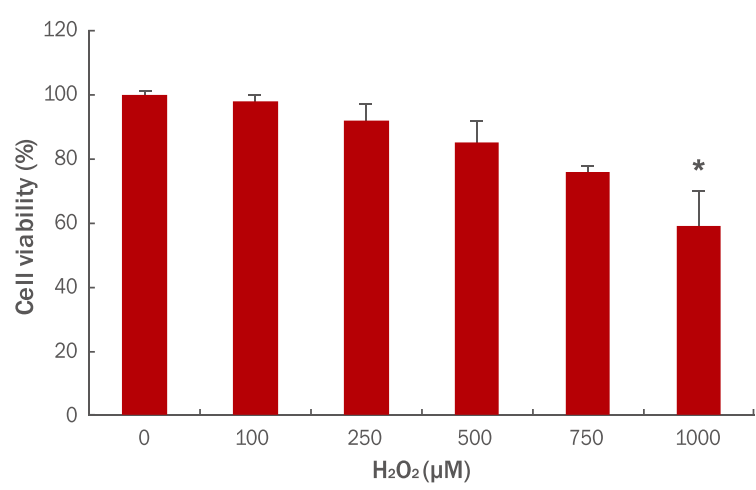

Figure 2. Analysis of cytotoxic effects of $\mathrm{H}_{2} \mathrm{O}_{2}$ in HaCaT keratinocytes. The cytotoxicity of $\mathrm{H}_{2} \mathrm{O}_{2}$ on $\mathrm{HaCaT}$ cells was tested by performing WST-1 assay. HaCaT cells $\left(3 \times 10^{3}\right.$ cells/well) were seeded on 96well plates and then treated with each of indicated concentration of $\mathrm{H}_{2} \mathrm{O}_{2}$ for $6 \mathrm{~h}$. The data are expressed as $\mathrm{M} \pm \mathrm{SD}$ from three independent experiments. ${ }^{*} p<0.05 . \mathrm{H}_{2} \mathrm{O}_{2}$, hydrogen peroxide; WST-1, water-soluble tetrazolium salt; $\mathrm{M} \pm \mathrm{SD}$, mean \pm standard deviation.

형성세포(HaCaT keratinocyte cell line)에서 항산화 효능을 확인함으로써, phytol의 화장품 소재로서의 가능성을 평가하 였다.

\section{Methods}

\section{1. 세포배양}

본 연구에서는 인간각질형성세포주인 HaCaT keratinocyte cell line을 American Type Culture Collection (ATCC; $\mathrm{USA}$ )에서 구매하여 사용하였다. $\mathrm{HaCaT}$ 세포주의 배양은 Dulbecco's modified Eagles medium (DMEM; Hyclone ${ }^{\mathrm{TM}}$, GE Healthcare Life Sciences, UK)에 10\% fetal bovine serum (FBS; Hyclone ${ }^{\mathrm{TM}}$ ), 1\% penicillin/streptomycin (penicillin $100 \mathrm{IU} / \mathrm{mL}$, streptomycin $100 \mu \mathrm{g} / \mathrm{mL}$; Invitrogen $^{\mathrm{TM}}$, Thermo Fisher Scientific, USA)가 첨가된 배 지를 사용하였고, $37^{\circ} \mathrm{C}, 5 \% \mathrm{CO}_{2}$ 조건에서 배양하였다.

\section{2. 세포생존율 측정}

$\mathrm{HaCaT}$ keratinocytes에서 phytol과 $\mathrm{H}_{2} \mathrm{O}_{2}$ 의 세포독성을 확 인하기 위하여 WST-1 assay를 이용하였다. WST-1 assay는 세포 내 미토콘드리아의 탈수소효소에 의해 tetrazolium salt 가 formazan으로 환원되는 방식을 이용하여 세포생존율을 측 정하는 시험방법이다.

Phytol (Sigma-Aldrich, USA)은 순수정제(>97\%)된 
powder 형태로 구매하였고, dimethyl sulfoxide (DMSO; Sigma-Aldrich)에 용해하여 실험에 사용하였다. Phytol과 $\mathrm{H}_{2} \mathrm{O}_{2}$ 각각의 세포독성을 확인하기 위하여 96-well plate에 HaCaT keratinocytes $\left(3 \times 10^{3}\right.$ cells/well)을 $100 \mu \mathrm{L}$ 씩 접종 하여 $24 \mathrm{~h}$ 배양하였다. Phytol은 HaCaT keratinocytes에 1 , $2,5,10,20 \mu \mathrm{M}$ 의 농도로 처리하여 $24 \mathrm{~h}$ 동안 배양하였고, $\mathrm{H}_{2} \mathrm{O}_{2}$ 는 $100,250,500,750,1000 \mu \mathrm{M}$ 의 농도로 $6 \mathrm{~h}$ 동안 배양하였다. EZ-Cytox Cell Viability Assay Kit Reagent (ItsBio, Korea)를 $10 \mu \mathrm{L}$ 씩 첨가하고 $1 \mathrm{~h}$ 배양 후 microplate reader (Bio-Rad Laboratories, USA)를 사용하여 $490 \mathrm{~nm}$ 에서 흡광도를 측정하였다. 세포생존율은 3 회 반복하여 세포 생존율의 평균값과 표준편차를 도출하였다.

\section{3. 세포보호 효과 측정}

$\mathrm{H}_{2} \mathrm{O}_{2}$ 에 대한 phytol의 세포보호 효과를 확인하기 위하 여 96-well plate에 HaCaT keratinocytes $\left(3 \times 10^{3}\right.$ cells/ well)를 $100 \mu \mathrm{L}$ 씩 접종하여 $24 \mathrm{~h}$ 배양하였다. Phytol을 1 , $5,10,20 \mu \mathrm{M}$ 의 농도로 $24 \mathrm{~h}$ 동안 배양한 다음, phosphate buffered saline (PBS; Sigma-Aldrich) washing 후 750 $\mu \mathrm{M} \mathrm{H} \mathrm{H}_{2} \mathrm{O}_{2}$ 를 $6 \mathrm{~h}$ 동안 처리한 후 WST-1 assay를 수행하여 흡광도를 측정하였다. 세포생존율은 3 회 반복하여 세포생존 율의 평균값과 표준편차를 도출하였다.

\section{DPPH 라디칼 소거 활성 측정}

항산화 효과를 측정하기 위해 화학적으로 안정화된 $\mathrm{DPPH}$ free radical이 항산화 활성이 있는 물질을 만나면 색상이 변 화하는 원리를 이용하여 실험을 진행하였다. 96-well plate 에 최종농도 $1,5,10 \mu \mathrm{M}$ 의 phytol 희석액를 $100 \mu \mathrm{L}$ 씩 분주 하고 여기에 $50 \mu \mathrm{L} \mathrm{DPPH}$ (최종농도 $0.2 \mathrm{mM}$ )을 넣은 후 암 실에서 $30 \mathrm{~min}$ 동안 방치하였다. Microplate reader를 이용 하여 흡광도 $514 \mathrm{~nm}$ 에서 측정하였으며, 대조군으로는 항산 화 물질로 잘 알려진 L-ascorbic acid를 사용하여 비교 실험 하였다. 실험 측정은 3 회 반복하여 흡광도의 평균값과 표준편 차를 도출하였다.

\section{5. 세포 내 ROS 정량 분석}

세포 내 ROS 변화를 측정하기 위해 DCFDA assay를 이용 하였다. HaCaT를 $2 \times 10^{5}$ cells/well로 $60 \mathrm{~mm}$ 배양접시에 접종하여 $24 \mathrm{~h}$ 배양한 다음, $5,10 \mu \mathrm{M}$ 농도의 phytol을 24 $\mathrm{h}$ 전처리하고, PBS washing 후 $750 \mu \mathrm{M} \mathrm{H}_{2} \mathrm{O}_{2}$ 를 $6 \mathrm{~h}$ 후처리 하여 추가 배양하였다. 세포 내 ROS을 측정하기 위한 dye인 $\mathrm{DCFDA}$ (Sigma-Aldrich)를 $10 \mu \mathrm{M}$ 첨가하여 $30 \mathrm{~min}$ 배양 후 세포를 수확하여 $\mathrm{PBS}$ 를 첨가하여 세포를 풀어준 후 $\mathrm{BD}$ FACSCalibur $^{\mathrm{TM}}$ Flow Cytometer (BD Biosciences, USA) 를 이용하여 ROS의 변화량을 측정하였다. Phytol의 ROS 제거 효능을 검증하기 위하여 ROS scavenger 역할을 하는 $\mathrm{L}-\mathrm{ascorbic}$ acid 역시 동일한 방식으로 측정하여 비교 · 분석 하였다.

\section{6. 항산화 관련 유전자의 발현 분석}

산화적 스트레스 상황에서 phytol이 항산화 효소인 $S O D$ 와 $C A T$ 의 유전자 발현에 미치는 영향을 확인하기 위하여 $\mathrm{HaCaT}$ 를 $2 \times 10^{5}$ cells/well로 $60 \mathrm{~mm}$ 배양접시에 접종하 여 $24 \mathrm{~h}$ 배양하였다. Phytol을 $1,5,10 \mu \mathrm{M}$ 농도로 $24 \mathrm{~h}$ 전 처리하고, PBS washing 후 $750 \mu \mathrm{M} \mathrm{H}_{2} \mathrm{O}_{2}$ 를 $6 \mathrm{~h}$ 후처리하 여 추가 배양하였다. $\mathrm{qRT}-\mathrm{PCR}$ 분석을 위해 세포배양 후 수 확한 세포를 TRIzol ${ }^{\circledR}$ reagent (Invitrogen ${ }^{\mathrm{TM}}$ )에 용해한 다 음, $0.2 \mathrm{~mL}$ chloroform (Biopure, Austria)를 첨가하여 상 온에 방치하였다. mRNA는 diethylpyrocarbonate (DEPC; Biopure) water로 녹여 실험에 사용하였으며, 추출된 RNA 는 Nanodrop (MaestroGen, Taiwan)을 이용하여 260/280 $\mathrm{nm}$ 의 ratio 1.8 이상 순도의 RNA만을 실험에 사용하였다. $S O D 1, S O D 2$ 및 CAT mRNA에 대한 qRT-PCR 분석을 실 시하였으며, PCR의 유효성은 melting curve로 검증하였고, 각 유전자의 발현은 actin beta $(A C T B)$ 로 표준화하여 비교 . 분석하였다(Table 1).

\section{GSH 측정}

세포 내 항산화 지표인 GSH 발현 변화를 측정하기 위해 발광기법에 기초하여 측정하는 방법(luminescence-based assay), GSH-Glo ${ }^{\mathrm{mx}}$ Glutathione Assay (Promega, USA)

Table 1. Lists of primers used in this study

\begin{tabular}{lll}
\hline Gene & Forward primer $\left(5^{\prime} \rightarrow 3^{\prime}\right)$ & \\
SOD1 & GGGAGATGGCCCAACTACTG & Reverse primer $\left(5^{\prime} \rightarrow 3^{\prime}\right)$ \\
SOD2 & GCCCTGGAACCTCACATCAA & CCAGTTGACATGCAACCGTT \\
CAT & ATGGTCCATGCTCTCAAACC & GGTACTTCTCCTCGGTGACGTT \\
ACTB & GGATTCCTATGTGGGCGACGA & CAGGTCATCCAATAGGAAGG \\
\hline
\end{tabular}

SOD1, CuZn-SOD, copper-zinc superoxide dismutase; SOD2, Mn-SOD, manganese superoxide dismutase; CAT, catalase; $A C T B$, actin beta. 


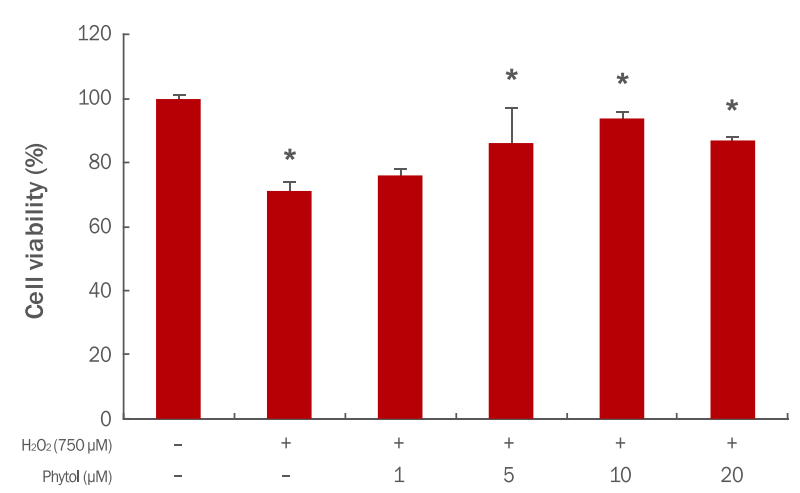

Figure 3. Cytoprotective effects of phytol against $\mathrm{H}_{2} \mathrm{O}_{2}$ in HaCaT keratinocytes.

Protective effects of phytol on cell viability in $\mathrm{H}_{2} \mathrm{O}_{2}$-treated $\mathrm{HaCaT}$ keratinocytes were tested by performing WST-1 assay. After seeding HaCaT cells $\left(3 \times 10^{3}\right.$ cells/well) on 96 -well plates with indicated concentrations of phytol, the cells were incubated for $24 \mathrm{~h}$. The cells were washed with PBS, then they were exposed to $750 \mu \mathrm{M} \mathrm{H}_{2} \mathrm{O}_{2}$ for $6 \mathrm{~h}$. The data are expressed as $\mathrm{M} \pm \mathrm{SD}$ from three independent experiments $\left({ }^{*} p<0.05\right) . \mathrm{H}_{2} \mathrm{O}_{2}$, hydrogen peroxide; WST-1, water-soluble tetrazolium salt; PBS, phosphate buffered saline; $\mathrm{M} \pm \mathrm{SD}$, mean \pm standard deviation.

를 사용하였다. $\mathrm{HaCaT}$ 를 $3 \times 10^{3}$ cells/well로 96-well plate에 접종하여 $24 \mathrm{~h}$ 배양하였다. Phytol을 $1,5,10 \mu \mathrm{M}$ 농도로 $24 \mathrm{~h}$ 전처리하고, $\mathrm{PBS}$ washing 후 $750 \mu \mathrm{M} \mathrm{H}_{2} \mathrm{O}_{2}$ 를 $6 \mathrm{~h}$ 후처리하여 추가 배양하였다. 배양접시에 시료를 처 리한 세포에 GSH-Glo ${ }^{\mathrm{m}}$ reagent $100 \mu \mathrm{L} /$ well를 첨가하 여 $30 \mathrm{~min}$ 동안 상온에서 반응시켰다. 그 후에 $15 \mathrm{~min}$ 동 안 luciferin detection reagent $100 \mu \mathrm{L} /$ well를 이용하여 반 응시키고, Synergy H1 Hybrid Multi-Mode Microplate Reader (BioTek Instruments, USA)를 이용하여 404/526 $\mathrm{nm}$ 에서 발광정도를 측정하였다.

\section{8. 통계처리}

본 연구의 모든 실험은 동일한 조건하에 독립적으로 3 회 이상 실시하였고, 각 실험은 paired $t$-test를 이용하여 $p$-value를 구하고 모든 실험 결과 $p$-value 값이 0.05 이하 인 경우에 통계적으로 유의하다고 분석하였다.

\section{Results and Discussion}

\section{1. 인간각질형성세포에서 $\mathrm{H}_{2} \mathrm{O}_{2}$ 에 의한 세포독성}

$\mathrm{HaCaT}$ keratinocytes에 $\mathrm{H}_{2} \mathrm{O}_{2}$ 를 사용하여 산화적 스트 레스를 유도하고 세포생존 회복률의 변화를 확인하기 위해, $\mathrm{HaCaT}$ keratinocytes에 $\mathrm{H}_{2} \mathrm{O}_{2}$ 를 100, 250, 500, 750, 1000

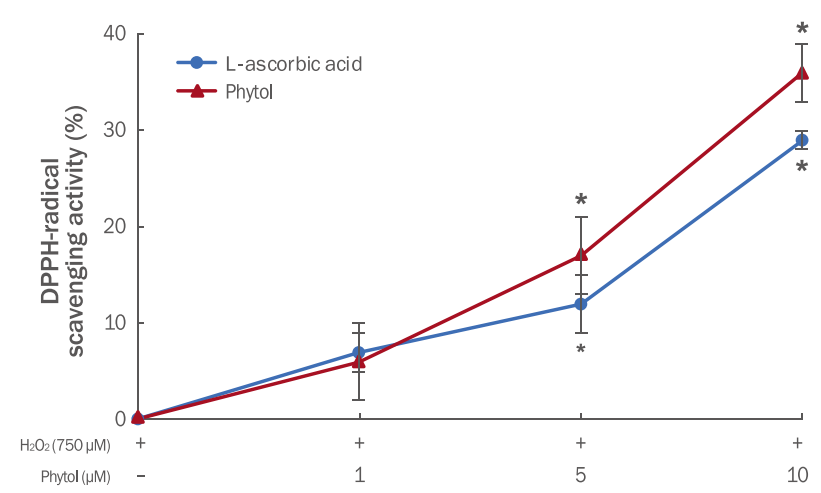

Figure 4. Anti-oxidant effects of phytol via DPPH radical scavenging activity.

DPPH free radical scavenging activities were estimated to evaluate anti-oxidant activity of phytol. HaCaT cells on 96-well plates with indicated concentrations of phytol were incubated in the dark with DPPH for $30 \mathrm{~min}$. Each sample was measured at $514 \mathrm{~nm}$ absorbance. The L-ascorbic acid was used as a positive control. The data are expressed as $\mathrm{M} \pm \mathrm{SD}$ from three independent experiments ( ${ }^{*} p<0.05$ ). DPPH, 2,2-diphenyl-1-picrylhydrazyl; $\mathrm{H}_{2} \mathrm{O}_{2}$, hydrogen peroxide; $\mathrm{M} \pm \mathrm{SD}$, mean \pm standard deviation.

$\mu \mathrm{M}$ 농도로 $6 \mathrm{~h}$ 동안 처리한 후 WST-1 assay로 측정하였 다. $\mathrm{H}_{2} \mathrm{O}_{2}$ 무처리 대조군의 세포생존율 $(100 \%)$ 을 기준으로 하 고, $100,250,500,750,1000 \mu \mathrm{M} \mathrm{H}_{2} \mathrm{O}_{2}$ 처리시 $98 \%, 92 \%$, $85 \%, 76 \%, 59 \%$ 의 세포생존율을 확인하였다(Figure 2). 따 라서 본 연구에서는 세포생존율이 적어도 $70 \%$ 이상인 $\mathrm{H}_{2} \mathrm{O}_{2}$ $750 \mu \mathrm{M}$ 을 실험에 사용하기로 결정하였다.

\section{2. $\mathrm{H}_{2} \mathrm{O}_{2}$ 에 대한 phytol의 세포보호 효과}

$\mathrm{H}_{2} \mathrm{O}_{2}$ 에 대한 phytol의 세포보호 효과를 확인하기 위하 여 HaCaT keratinocytes에 phytol을 농도별로 배양한 다 음 $\mathrm{H}_{2} \mathrm{O}_{2}$ 을 처리한 후, WST-1 assay를 실시하였다. Phytol 과 $\mathrm{H}_{2} \mathrm{O}_{2}$ 무처리군 세포생존율 $(100 \%)$ 을 기준으로 $750 \mu \mathrm{M}$ $\mathrm{H}_{2} \mathrm{O}_{2}$ 단독 처리시 세포생존율이 $71 \%$ 로 감소함을 확인하 였다. Phytol을 $1,5,10 \mu \mathrm{M}$ 농도로 처리한 후 $\mathrm{H}_{2} \mathrm{O}_{2}$ 처리 된 $\mathrm{HaCaT}$ keratinocytes에서는 세포생존율이 $76 \%, 86 \%$, $94 \%$ 로 세포생존율이 농도 의존적으로 증가하였으나, $20 \mu \mathrm{M}$ phytol 처리된 HaCaT keratinocytes는 세포생존율이 87\% 로 phytol $10 \mu \mathrm{M}$ 에 비해 감소하였다(Figure 3). 따라서 향후 실험은 $1,5,10 \mu \mathrm{M}$ 농도를 사용하기로 결정하였으며, 이상 의 결과를 통해 $\mathrm{H}_{2} \mathrm{O}_{2}$ 로 인해 유발된 산화적 스트레스에 의한 HaCaT keratinocytes 손상으로부터 phytol의 세포보호 효 과를 확인하였다.

\section{Phytol의 DPPH 라디칼 소거 활성}




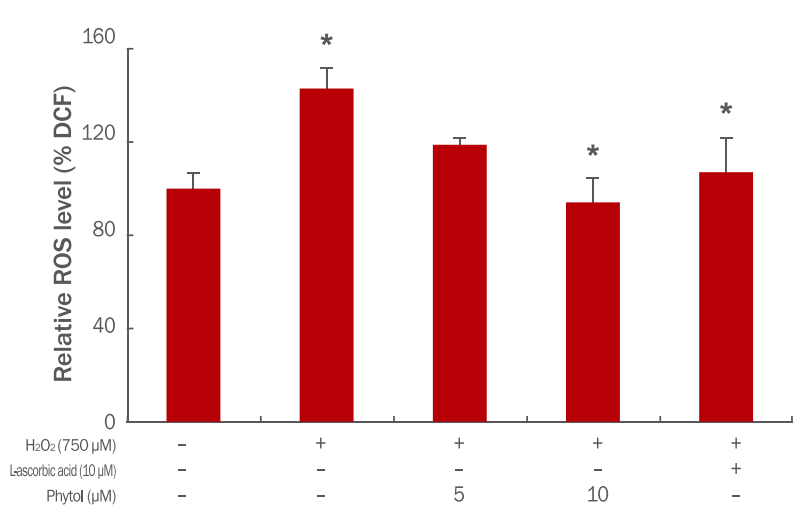

Figure 5. Effects of phytol on the $\mathrm{H}_{2} \mathrm{O}_{2}$ induced intracellular ROS levels using the DCFDA in HaCaT keratinocytes.

ROS scavenging effects of phytol in $\mathrm{H}_{2} \mathrm{O}_{2}$-treated $\mathrm{HaCaT}$ keratinocytes were tested by performing DCFDA assay. HaCaT cells $\left(2 \times 10^{5}\right.$ cells/well) were seeded and then treated with the indicated concentrations of phytol and L-ascorbic acid for $24 \mathrm{~h}$. Then, the cells were washed with PBS and exposed to $750 \mu \mathrm{M} \mathrm{H}_{2} \mathrm{O}_{2}$ for 6 h. They were placed with $10 \mu \mathrm{M}$ DCFDA for $30 \mathrm{~min}$. Later, ROS scavenging of phytol and L-ascorbic acid were measured by flow cytometer. The L-ascorbic acid was used as a positive control. The data are expressed as $\mathrm{M} \pm \mathrm{SD}$ from three independent experiments $\left({ }^{*} p<0.05\right)$. ROS, reactive oxygen species; DCFDA, 2',7'-dichlorofluorescin diacetate; $\mathrm{H}_{2} \mathrm{O}_{2}$, hydrogen peroxide; PBS, phosphate buffered saline; $\mathrm{M} \pm \mathrm{SD}$, mean \pm standard deviation.

Phytol의 항산화 효능을 확인하기 위하여 가장 보편적인 항산화 측정 방법인 $\mathrm{DPPH}$ radical 소거 활성을 이용하였다. $\mathrm{DPPH}$ 는 화학적으로 안정화된 free radical을 가지며, 514 $\mathrm{nm}$ 에서 특이적인 광흡수를 나타내는 진한 보라색 화합물 로, 항산화 활성이 있는 물질과 만나면 전자를 내어주고 free radical이 소멸되어 정량적으로 탈색된다. 본 연구에서 $\mathrm{H}_{2} \mathrm{O}_{2}$ 에 의한 $\mathrm{HaCaT}$ keratinocytes 생장 저해 및 사멸을 억제하 는 phytol의 항산화 효과를 확인한 결과, phytol을 $1,5,10$ $\mu \mathrm{M}$ 처리시 $\mathrm{DPPH}$ 라디칼 소거 활성이 $6 \%, 17 \%, 36 \%$ 로 농도 의존적으로 증가하였다. 양성대조군인 L-ascorbic acid를 1 , $5,10 \mu \mathrm{M}$ 처리시에는 $\mathrm{DPPH}$ 라디칼 소거 활성이 $7 \%, 12 \%$, $29 \%$ 로 증가하여 phytol이 양성대조군에 비해 항산화 효과가 높음을 확인하였다(Figure 4).

\section{Phytol의 세포 내 ROS 억제 활성}

Phytol이 HaCaT keratinocytes 세포 내 ROS에 미치는 영향을 알아보기 위해 DCFDA assay를 이용하였다. ROS 측 정 도구인 DCFDA assay는 세포막 투과 후 활성산소와 반 응하여 형광을 나타내며 산화적 스트레스에 의한 세포손상을 측정하기 위한 방법으로 보편적으로 사용되고 있다. ROS 소 거 효능으로 잘 알려진 L-ascorbic acid과 phytol을 HaCaT keratinocytes에 처리하여 ROS 소거 효과를 비교 확인하였
다. Phytol이 $\mathrm{H}_{2} \mathrm{O}_{2}$ 에 의해 세포 내 발생하는 ROS의 억제 효 능을 확인한 결과, $\mathrm{HaCaT}$ keratinocytes 에 $\mathrm{H}_{2} \mathrm{O}_{2}$ 를 $750 \mu \mathrm{M}$ 처리시 $\mathrm{H}_{2} \mathrm{O}_{2}$ 를 처리하지 않았을 때 보다 $\mathrm{ROS}$ 가 $143 \%$ 로 증 가하였으나 phytol를 $5,10 \mu \mathrm{M}$ 처리시 $119 \%, 94 \%$ 로 ROS가 감소되었다. 양성대조군인 L-ascorbic acid를 $10 \mu \mathrm{M}$ 처리시 에는 ROS가 $107 \%$ 측정되어, phytol이 L-ascorbic acid보다 높은 항산화 효과를 나타내는 것을 확인하였다(Figure 5).

\section{Phytol의 항산화 유전자 발현 촉진 효과}

인체에서 대표적인 1차 항산화 효소인 $\mathrm{SOD}$ 는 산화적 스 트레스를 일으키는 $\mathrm{ROS}$ 중 $\mathrm{O}_{2}{ }^{-}$을 $\mathrm{H}_{2} \mathrm{O}_{2}$ 와 산소로 전환시키 는 효소이다(Allen \& Tresini, 2000; Shull et al., 1991). 포유류에서 $\mathrm{SOD}$ family는 $\mathrm{SOD}$ 활성중심 부위에 존재 하는 산화 - 환원 금속이온의 종류에 따라 SOD1, SOD2, extracellular superoxide dismutase (EC-SOD; SOD3) 로 분류된다. SOD1은 세포질에서, SOD2는 미토콘드리아 에서, $\mathrm{SOD} 3$ 는 세포 바깥쪽에 존재하며, 세 가지 $\mathrm{SOD}$ 의 기 능은 비슷하지만 염색체 위치나 단백질 구조는 서로 다르다 (Frederiks \& Bosch, 1997; Zelko et al., 2002). CAT는 항 산화 효소로 산소호흡으로 생명을 유지하는 생물들의 생체 내 에서 필연적으로 발생하는 $\mathrm{ROS}$ 중 하나인 $\mathrm{H}_{2} \mathrm{O}_{2}$ 를 물과 산소 로 분해한다. $\mathrm{CAT}$ 는 고등동물이나 식물에서부터 미생물에 이 르기까지 광범위하게 발견된다(Brioukhanov \& Netrusov, 2004).

항산화 효소 $\mathrm{SOD}$ 에 의해 생성된 $\mathrm{H}_{2} \mathrm{O}_{2}$ 는 $\mathrm{GPx}$ 가 $\mathrm{GSH}$ 를 GSSG로 산화시키면서 소거된다. GSSG는 glutathione reductase (GR)에 의해 다시 GSH로 환원되어 인체 내에서 glutathione은 GSH와 GSSG의 두 가지 형태로 균형을 이 루면서 존재하게 된다. 일반적으로 세포 내에서 $98 \%$ 이상 이 GSH로 존재하고 $2 \%$ 가 산화적 스트레스에 의해서 산화형 으로 변환되어 GSSG로 존재한다(Aslund et al., 1997). 세 포 내에서 독성 또는 산화적 손상이 일어난 경우에는 GSSG 가 서서히 증가하여, $\mathrm{GSH} / \mathrm{GSSG}$ 의 균형이 파괴되어 방 어기전으로서의 역할이 소실된다. 이로써 세포의 GSH과 GSSG의 비율은 종종 세포독성의 지표로 사용된다(Hayes \& McLellan, 1999).

$\mathrm{GSH}$ 의 생체 내에서의 생리학적 기능은 매우 다양하지만 크게 두 가지의 주요 기능으로 나누어 볼 수 있다. 첫 번째, $\mathrm{GSH}$ 는 생체 내의 주요 항산화 성분으로 자신의 thiol를 이 용, 과산화수소와 반응하여 활성산소를 환원하여 생체 내에서 보다 쉽게 활성산소를 제거한다(Siliprandi et al., 1978). 두 번째 주요 생리학적 기능은 세포 내 cysteine의 제공자로서 다양한 독극물, 마약, 전달 물질 등이 cysteine 잔기의 thiol 과 결함됨으로서 이 결합체의 수용성을 증가시켜 세포 밖으로 

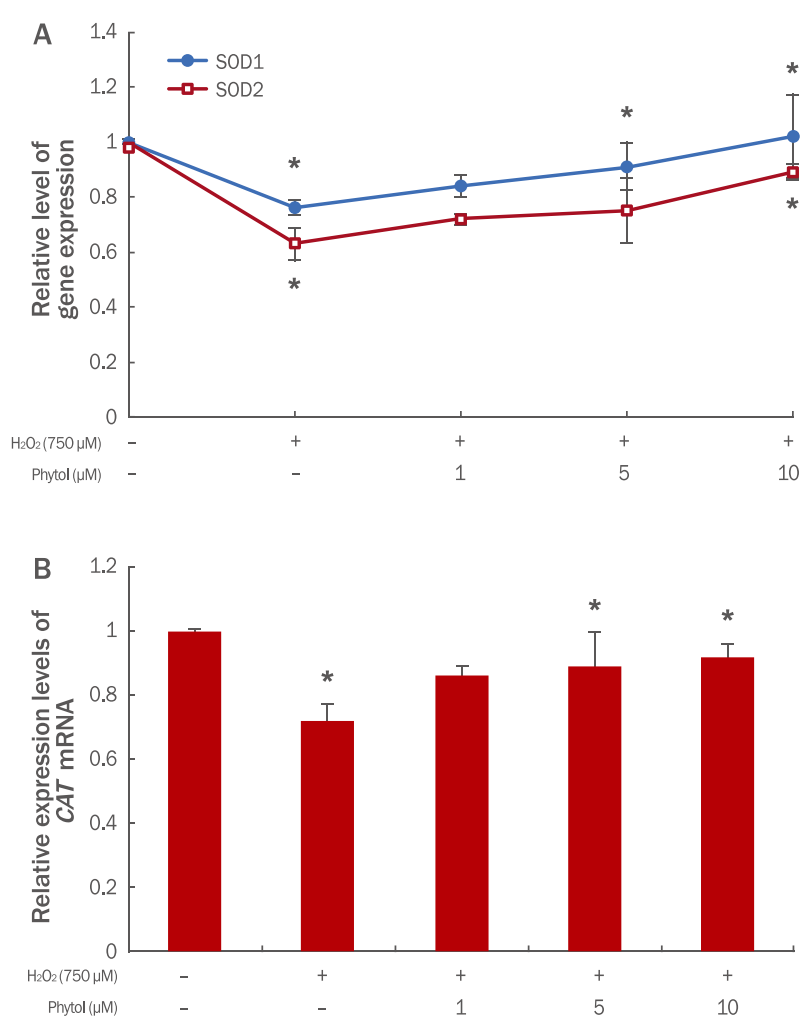

Figure 6. Effects of phytol on $\mathrm{H}_{2} \mathrm{O}_{2}$ induced anti-oxidant enzyme expression in HaCaT keratinocytes.

HaCaT cells $\left(2 \times 10^{5}\right.$ cells/well) were seeded and then treated with the indicated concentrations of phytol for $24 \mathrm{~h}$. Then, the cells were washed with PBS and exposed to $750 \mu \mathrm{M} \mathrm{H}_{2} \mathrm{O}_{2}$ for $6 \mathrm{~h}$. The expression of SOD1, SOD2 (A), and CAT (B) mRNA was determined using the qRT-PCR. The data are expressed as $\mathrm{M} \pm \mathrm{SD}$ from three independent experiments ( $\left.{ }^{*} p<0.05\right)$. SOD1, CuZn-SOD, copper-zinc superoxide dismutase; SOD2, Mn-SOD, manganese superoxide dismutase; $C A T$, catalase; $\mathrm{H}_{2} \mathrm{O}_{2}$, hydrogen peroxide; PBS, phosphate buffered saline; qRT-PCR, quantitative real-time polymerase chain reaction; $\mathrm{M} \pm \mathrm{SD}$, mean \pm standard deviation.

빠르게 배출시키는 역할을 한다. 따라서 GSH는 세포 내의 해 독작용을 한다(Dickinson \& Forman, 2002).

본 실험에서는 세포 내에 존재하는 항산화 유전자인 $S O D 1$, $S O D 2, C A T$ mRNA 및 GSH의 발현변화를 관찰하여 phytol 의 $\mathrm{HaCaT}$ keratinocytes에서 항산화 효과를 알아보았다. HaCaT keratinocytes에서 phytol이 SOD1, SOD2 mRNA 의 유전자 발현 변화에 미치는 영향을 확인한 결과, $\mathrm{H}_{2} \mathrm{O}_{2}$ 를 $750 \mu \mathrm{M}$ 처리시 SOD1, SOD2 mRNA의 발현량이 대조군에 비해 각각 0.76 배, 0.63 배 정도로 감소하였으나 phytol을 1 , $5,10 \mu \mathrm{M}$ 처리시 $S O D 1$ 는 0.84배, 0.91배, 1.02배로 $S O D 2$ 는 0.72 배, 0.75 배, 0.89 배로 모두 농도 의존적으로 증가하 여 ROS가 소거되고 있음을 확인하였다(Figure 6A).

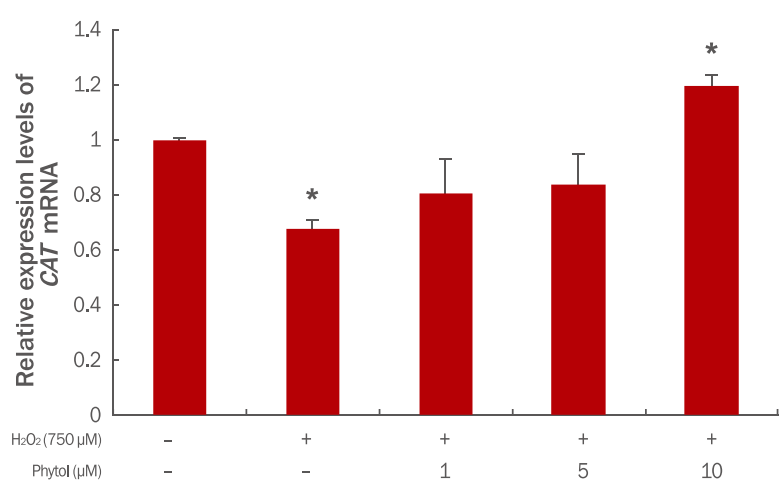

Figure 7. Effects of phytol on $\mathrm{H}_{2} \mathrm{O}_{2}$ induced the expression level of intracellular GSH in HaCaT keratinocytes.

HaCaT cells $\left(3 \times 10^{3}\right.$ cells/well) on 96-well plates were seeded, then treated with the indicated concentrations of phytol for 24 $\mathrm{h}$. The cells were washed with PBS, and then they were exposed to $750 \mu \mathrm{M} \mathrm{H}_{2} \mathrm{O}_{2}$ for $6 \mathrm{~h}$. GSH-Glo ${ }^{\mathrm{TM}}$ reagent was applied to $\mathrm{HaCaT}$ cells in thiol-free buffer to stain them. The approximate fluorescence excitation and emission wavelength for GSH-GloTM reagent is $404 / 526 \mathrm{~nm}$, and flow cytometer was used. The data are expressed as $\mathrm{M} \pm \mathrm{SD}$ from three independent experiments $\left({ }^{*} p<0.05\right)$. GSH, reduced glutathione; $\mathrm{H}_{2} \mathrm{O}_{2}$, hydrogen peroxide; PBS, phosphate buffered saline; $M \pm S D$, mean \pm standard deviation.

$\mathrm{HaCaT}$ keratinocytes에서 노화 억제 기전에 있어 대표적 항산화 효소인 $C A T \mathrm{mRNA}$ 의 유전자 발현 변화를 확인한 결 과, $\mathrm{H}_{2} \mathrm{O}_{2}$ 를 $750 \mu \mathrm{M}$ 처리시 대조군에 비해 0.72 배로 감소하 였으나 phytol을 $1,5,10 \mu \mathrm{M}$ 처리시 $C A T$ mRNA의 유전자 발현량이 0.86 배, 0.89 배, 0.92 배로 농도 의존적으로 회복되 $\mathrm{HaCaT}$ keratinocytes에서 phytol이 노화 억제 기전에 있어 대표적 항산화 지표인 GSH 발현 변화를 확인한 결과, $\mathrm{H}_{2} \mathrm{O}_{2}$ 를 $750 \mu \mathrm{M}$ 처리시 대조군에 비해 0.68 배로 감소하였으나 phytol을 $1,5,10 \mu \mathrm{M}$ 처리시 GSH 발현량이 0.81 배, 0.84 배, 1.20 배로 농도 의존적으로 회복되어 phytol의 항산화 효 과를 확인하였다(Figure 7).

\section{Conclusion}

본 논문은 $\mathrm{HaCaT}$ keratinocytes에서의 phytol의 항산화 효능을 연구하였다. Phytol을 HaCaT keratinocytes에 $24 \mathrm{~h}$ 전처리 후 산화적 스트레스를 유발하는 $\mathrm{H}_{2} \mathrm{O}_{2}$ 를 $6 \mathrm{~h}$ 후처리 하였다. 그 후 phytol의 세포보호 효과를 검증하기 위해서 세 포생존율, DPPH assay, ROS scavenging activity assay, qRT-PCR, flow cytometry analysis, glutathione assay를 실시하였다.

Phytol의 항산화 효능을 알아보기 위해 $\mathrm{DPPH}, \mathrm{ROS}$ 정량 
분석, $S O D 1, S O D 2, C A T$ mRNA qRT-PCR, GSH 측정 실 험을 실시하였다. 그 결과 $\mathrm{DPPH}$ 라디칼 소거 정도가 양성 대조군인 L-ascorbic acid와 유사한 정도로 나타났으며, 세 포 내에서 발생하는 ROS는 phytol에 의해 농도 의존적으로 소거되었음을 확인하였다. 항산화 유전자로 알려진 $S O D 1$, $S O D 2, C A T$ mRNA는 phytol에 의해 농도 의존적으로 발현 이 증가하였고, GSH 또한 phytol 농도 의존적으로 증가하여 phytol의 항산화 효능을 확인하였다. 본 연구를 통해 phytol 의 항산화 활성을 검증하였고, 이러한 연구결과를 통해 잠재 적인 노화예방 화장품 소재로서 phytol의 활용 가능성을 알아 보았다.

This work is part of the Sun-Hee Jeong's Ph.D. thesis at the Konkuk University, Seoul, Korea.

\section{Acknowledgements}

본 논문이 완성되기까지 많은 조언을 주신 안성관 지도교수 님께 감사드립니다.

\section{References}

Allen RG, Tresini M. Oxidative stress and gene regulation. Free Radical Biology and Medicine, 28: 463-499, 2000.

Aslund F, Berndt KD, Holmgren A. Redox potentials of glutaredoxins and other thiol-disulfide oxidoreductases of the thioredoxin superfamily determined by direct protein-protein redox equilibria. The Journal of Biological Chemistry, 272: 30780-30786, 1997.

Brioukhanov AL, Netrusov Al. Catalase and superoxide dismutase: distribution, properties, and physiological role in cells of strict anaerobes. Biochemistry (Moscow), 69: 949-962, 2004.

Dickinson DA, Forman HJ. Glutathione in defense and signaling: lessons from a small thiol. Annals of the New York Academy of Sciences, 973: 488-504, 2002.

Frederiks WM, Bosch KS. Localization of superoxide dismutase activity in rat tissues. Free Radical Biology and Medicine, 22: 241-248, 1997.

Gao Z, Huang K, Xu H. Protective effects of flavonoids in the roots of Scutellaria baicalensis Georgi against hydrogen peroxide-induced oxidative stress in HS-SY5Y cells. Pharmacological Research, 43: 173-178, 2001.
Gross J. Pigments in vegetables: chlorophylls and carotenoids. Springer Publishing, New York, pp29-30, 1991.

Halliwell B, Gutteridge JM. Free radicals in biology and medicine. Clarendon Press, Oxford, pp86-89, 1989.

Hayes JD, McLellan LI. Glutathione and glutathionedependent enzymes represent a co-ordinately regulated defence against oxidative stress. Free Radical Research, 31: 273-300, 1999.

Lee NK, Ku JE, Han HS. Cytoprotective and antiinflammatory effects of 6-shogaol on human dermal fibroblasts. Asian Journal of Beauty and Cosmetology, 15: 367-376, 2017.

Ozben T. Oxidative stress and apoptosis: impact on cancer therapy. Journal of Pharmaceutical Sciences, 96: 21812196, 2007.

Park S, Shim JH. Anti-aging effect of Psoraleae Fructus extract in UVA-irradiated HaCaT Cells. Asian Journal of Beauty and Cosmetology, 14: 119-126, 2016.

Rhee SG. $\mathrm{H}_{2} \mathrm{O}_{2}$, a necessary evil for cell signaling. Science, 312: 1882-1883, 2006.

Shull S, Heintz NH, Periasamy M, Manohar M, Janssen YM, Marsh JP, Mossman BT. Differential regulation of antioxidant enzymes in response to oxidants. The Journal of Biological Chemistry, 266: 24398-24403, 1991.

Siliprandi N, Siliprandi D, Bindoli A, Toninello A. Effect of oxidation of glutathione and membrane thiol groups on mitochondrial functions. In: functions of glutathione in liver and kidney. Sies H, Wendel A (ed.), Springer Science+Business Media, Berlin, pp139-147, 1978.

Slater TF. Free-radical mechanisms in tissue injury. Biochemical Journal, 222: 1-15, 1984.

Thannickal VJ, Fanburg BL. Reactive oxygen species in cell signaling. American Journal of Physiology - Lung Cellular and Molecular Physiology, 279: 1005-1028, 2000.

Zelko IN, Mariani TJ, Folz RJ. Superoxide dismutase multigene family: a comparison of the CuZn-SOD (SOD1), Mn-SOD (SOD2), and EC-SOD (SOD3) gene structures, evolution, and expression. Free Radical Biology and Medicine, 33: 337-349, 2002. 


\section{국문초록}

\section{인간각질형성세포에서 Phytol의 항산화 효능}

정선희

수원여자대학교 미용예술과, 경기도 수원시, 한국

목적: 본 연구는 인간각질형성세포에서 phytol의 항산화, 세포보호 효능을 검증하여 화장품 소재로서의 가능성을 알아보 는데 목적이 있다. 방법: Phytol의 효능을 검증하기 위해 세포생존율, 2,2-diphenyl-1-picrylhydrazyl (DPPH) assay, 2,7' -dichlorofluorescin diacetate (DCFDA) assay, reactive oxygen species (ROS) scavenging activity assay, flow cytometry analysis, quantitative real-time polymerase chain reaction (qRT-PCR), glutathione assay를 실시하였다. 결과: 인간각질형성세포에서 $\mathrm{H}_{2} \mathrm{O}_{2}$ 와 phytol의 실험농도를 결정하기 위해, 다양한 농도로 water-soluble tetrazolium salt (WST-1) assay를 실시하였다. 실험결 과에 따라 $\mathrm{H}_{2} \mathrm{O}_{2}$ 는 $750 \mu \mathrm{M}$, phytolo은 최대 $10 \mu \mathrm{M}$ 을 실험에 사용하였다. 항산화 유전자로 잘 알려진 SOD1, SOD2, CAT mRNA는 phytol 농도 의존적으로 발현이 증가하였고, GSH 또한 phytol 농도 의존적으로 증가하여 항산화 기능이 회복되는 것을 확인하였다. 결론: 이상의 실험들을 통해 phytol의 항산화 효과 및 인간각질형성세포 보호효능을 검증하였으며 잠재적인 노화억제 화장품 소재로 서 활용가능성을 제시하였다.

핵심어: Phytol, 항산화, 세포보호, 화장품, 노화

본 논문이 완성되기까지 많은 조언을 주신 안성관 지도교수님께 감사드립니다.

\section{참고문헌}

박선영, 심중현. 자외선 조사에 의해 노화된 $\mathrm{HaCaT}$ 세포에서 보골지 추출물의 항노화 효능. 아시안뷰티화장품학술지, $14:$ 119-126, 2016.

이나경, 구정은, 한효선. 인간진피섬유아세포에서 6-Shogaol의 세포보호 및 항염증 효과. 아시안뷰티화장품학술지, 15: 367376, 2017. 


\section{中文摘要}

\section{人角质形成细胞中phytol的抗氧化效能}

鄭善熙

水原女子大学美容艺术科, 京畿道水原市, 韩国

目的: 鉴定人角质形成细胞中phytol的抗氧化和细胞保护效能, 探索作为化妆品原料的可行性。方法: 为确定phytol的效 能, 进行细胞生存率, 2,2-diphenyl-1-picrylhydrazyl (DPPH) assay, 2',7'-dichlorofluorescin diacetate (DCFDA) assay, reactive oxygen species (ROS) scavenging activity assay, flow cytometry analysis, quantitative real-time polymerase chain reaction (qRT-PCR), glutathione assay等实验。结果: 在人角质形成细胞中, 为确定 $\mathrm{H}_{2} \mathrm{O}_{2}$ 和phytol的实验浓度, 对 不同浓度的phytol进行water-soluble tetrazolium salt (WST-1) assay。实验结果显示, $\mathrm{H}_{2} \mathrm{O}_{2}$ 的最佳实验浓度为 $750 \mu \mathrm{M}$ ， phytol的最大范围使用浓度为 $10 \mu \mathrm{M}$ 。抗氧化遗传因子SOD1、SOD2、CAT mRNA的表达程度根据浓度依赖性逐渐增加， GSH也根据浓度依赖性逐渐恢复其抗氧化能力。结论: 通过以上的实验结果, 鉴定了phytol的抗氧化效能以及人角质形成 细胞的保护效果, 因此作为潜在的抗衰老化妆品原料充分提出了活用可行性。

关键词: Phytol, 抗氧化, 细胞保护, 化妆品, 衰老 